Jurnal Health Sains: p-ISSN : 2723-4339 e-ISSN : 2548-1398

Vol. 2, No. 2, Februari 2021

\title{
HUBUNGAN PENGETAHUAN WANITA USIA SUBUR (WUS) TENTANG PAP SMEAR DENGAN KEIKUTSERTAAN MELAKUKAN PEMERIKSAAN PAP SMEAR
}

\section{Nopiyanti dan Febi Ratnasari}

Sekolah Tinggi Ilmu Kesehatan Yatsi, Tangerang, Banten, Indonesia

Email: nopinaryan@gmail.com dan febiratnasari14@gmail.com

\begin{tabular}{ll}
\hline ARTIKEL INFO & ABSTRACT \\
\hline Tanggal diterima: 5 Februari & The purpose of this literature review is to conclude \\
2021 & information and analyze research journals about the \\
Tanggal revisi: 15 Februari & relationship between fertile age women (WUS) knowledge \\
Tanggal yang diterima: 25 & about pap smears and participation in carrying out pap \\
Februari 2021 & smears. The design of this research is literature review or \\
\hline Keywords: & literature review. The period of time for the journal used is \\
knowledge; women of & a maximum journal publication period of 5 years (2014- \\
childbearing age; pap smear & 2019), using indonesian, adult human subjects, the type of \\
and cancer clients. & journal using original research articles and the theme of \\
& journal content is the theme of knowledge of fertile women \\
& (WUS) about pap smears with participation to do a pap \\
& smear examination. Searching for published articles on \\
& academic search complete, medline with full text, proquest \\
& and pubmed, EBSCO used the selected keywords: \\
knowledge, women of childbearing age, pap smears and & cancer clients. The author examines five research results on \\
the relationship between fertile age women (WUS) & knowledge about pap smears and participation in \\
conducting pap smears, the results show that five studies \\
from the articles that the author reviewed show that there is \\
a relationship between fertile age women (WUS) knowledge \\
about pap smears and participation. do a pap smear \\
examination.
\end{tabular}

\section{ABSTRAK}

Tujuan literature review ini untuk menyimpulkan informasi dan menganalisis jurnal penelitian tentang hubungan pengetahuan wanita usia subur (WUS) tentang pap smear dengan keikutsertaan melakukan pemeriksaan pap smear. Desain penelitian ini adalah literature review atau tinjauan pustaka. Jangka waktu jurnal yang digunakan adalah rentang waktu penerbitan jurnal maksimal 5 tahun (20142019), menggunakan bahasa Indonesia, subyek manusia dewasa, jenis jurnal menggunakan original artikel penelitian dan tema isi jurnal adalah tema pengetahuan wanita usia subur (WUS) tentang pap smear dengan keikutsertaan melakukan pemeriksaan pap smear. Penelusuran artikel publikasi pada academic search

Kata Kunci:

Pengetahuan; wanita usia complete, medline with full text, proquest dan pubmed, EBSCO menggunakan kata kunci yang dipilih yakni: pengetahuan, wanita usia subur, pap smear dan klien 
subur; pap smear dan klien kanker.

\begin{abstract}
kanker. Penulis menelaah lima hasil penelitian tentang hubungan pengetahuan wanita usia subur (WUS) tentang pap smear dengan keikutsertaan melakukan pemeriksaan pap smear, didapatkan hasil bahwa lima penelitian dari artikel yang penulis telaah menunjukan ada hubungan antara pengetahuan wanita usia subur (WUS) tentang pap smear dengan keikutsertaan melakukan pemeriksaan pap smear.
\end{abstract}

Coresponden Author:

Email: nopinaryan@gmail.com Artikel dengan akses terbuka dibawah lisensi

\section{Pendahuluan}

Kanker merupakan salah satu penyakit yang menyebabkan kematian terbesar saat ini. Berdasarkan data world health organization (WHO) tahun 2017 penyakit kanker serviks menempati urutan teratas di antara berbagai jenis kanker penyebab kematian pada perempuan di dunia, terdapat 490.000 perempuan di dunia setiap tahun didiagnosa terkena kanker serviks. Sedangkan 240.000 diantaranya mengalami kematian. Berdasarkan data world health organization (WHO) pada tahun 2017 diperkirakan setiap harinya ada 38 kasus baru kanker serviks dan 21 orang perempuan yang meninggal karena kanker serviks di indonesia. Pada tahun 2017, terdapat 530.202 kasus baru kanker serviks di seluruh dunia. Dengan jumlah itu berarti di perkirakan akan di dapatkan sekitar satu kasus baru kanker serviks setiap menitnya di dunia. Secara keseluruhan insiden kanker serviks di seluruh dunia adalah sebesar 16,2 per 100.000 penduduk (Ocviyanti et al., 2009).

Kanker mulut rahim di negara-negara maju menempati urutan keempat setelah kanker payudara, kolorektum, dan endometrium. Sedangkan di negara-negara sedang berkembang menempati urutan pertama. Di Negara Amerika Serikat, kanker Jurnal Health Sains Vol. 2, No. 2, Februari 2021 mulut rahim memiliki age specific incidence rate (ASR) yang khas, kurang lebih 20 kasus per 100.000 penduduk wanita per tahun. Untuk wilayah ASEAN, insidens kanker serviks di Singapura sebesar 25,0 pada ras cina, 17,8 pada ras melayu dan thailand sebesar 23,7 per 100.000 penduduk. Insidens dan angka kematian kanker serviks menurun selama beberapa dekade terakhir di AS. Hal ini karena skrining pap menjadi lebih populer dan lesi serviks pre-invasif lebih sering dideteksi daripada kanker invasif.

Di indonesia, kanker serviks menempati urutan kedua dari segi jumlah penderita kanker pada perempuan namun sebagai penyebab kematian masih menempati peringkat pertama terutama dalam stadium lanjut (Ocviyanti et al., 2009). Diagnosis kanker serviks pada stadium lanjut merupakan penyebab utama peningkatan morbiditas dan mortalitas (Nadia, 2017). Berdasarkan data $W H O$ pada tahun 2017 di indonesia diperkirakan setiap harinya ada 4045 kasus baru, 20-25 orang meninggal, berarti setiap satu jam diperkirakan satuorang perempuan meninggal dunia karena kanker serviks (Kemenkes, 2017). Dari data 17 rumah sakit di jakarta 1977, kanker serviks menduduki urutan pertama, yaitu 432 kasus di 
antara 918 kanker pada perempuan. Kementerian kesehatan sendiri mencatat, per 31 januari 2019, angka perempuan yang mengidap kanker payudara mencapai 42,1 persen per 100 ribu penduduk, dengan angka rata-rata kematian 17 orang per 100 ribu penduduk.

Ketua Badan Kerjasama Organisasi Wanita (BKOW) banten, Ade Rossi Khoerunnisa mengatakan, dari data yang di dapat BKOW terdapat 325 warga di banten yang mengidap kanker payudara, sedangkan 116 warga terkena kanker serviks. Maka dari itu, ia menilai penting ada sosialisasi terkait deteksi dini kanker payudara (RMOL Banten, 2019).

Informasi mengenai kanker serviks masih kurang dipahami oleh sebagian besar wanita usia subur (WUS). Rendahnya pengetahuan mengenai kanker serviks secara umum berhubungan dengan masih tingginya angka kejadian kanker serviks. Hal ini sangat memprihatinkan mengingat kanker serviks merupakan salah satu kanker yang dapat dicegah sejak dini dengan deteksi dini salah satunya adalah pap smear, di banten, cakupan wanita yang melakukan pap smear dan IVA tergolong masih sangat rendah, penelitian yang di lakukan oleh Setia (2018) dalam RMOL banten (2019) di Rsud kota tangerang mengatakan bahwa hasil penelitian tersebut didapatkan $17,6 \%$ responden memilih melakukan metode pap smear dan 82,4\% tidak memilih melakukan metode pap smear. Selain itu, paritas risiko tinggi sebanyak $24,7 \%$ dan risiko rendah $75,3 \%$ serta $48,2 \%$ berpengetahuan baik dan $51,8 \%$ berpengetahuan masih kurang.

Seringnya terjadi keterlambatan dalam diagnosa dan pengobatan pada stadium lanjut mengakibatkan banyaknya penderita kanker serviks meninggal dunia, padahal kanker serviks dapat diobati jika belum mencapai stadium lanjut, tentunya dengan mengetahui terlebih dahulu apakah sudah terinfeksi (YKI,
2014). Kanker serviks merupakan suatu penyakit yang disebabkan oleh HPV atau human papilloma virus, mempunyai presentase yang cukup tinggi dalam menyebabkan kanker serviks yaitu sekitar 99,7\% (Tilong, 2012). Lebih dari 70\% kanker serviks disebabkan oleh infeksi hPV tipe 16 dan 18. Infeksi hPV mempunyai prevalensi yang tinggi pada kelompok usia muda, sementara kanker serviks baru timbul pada usia tiga puluh tahunan atau lebih (Saifuddin, 2016).

Saat ini cakupan "screening" deteksi dini kanker serviks di indonesia (2015) melalui pap smear dan IVA masih sangat rendah (sekitar 5\%), padahal cakupan "screening" yang efektif dalam menurunkan angka kesakitan dan angka kematian karena kanker serviks adalah $85 \%$. Pada tahun 2025 di perkirakan kasus baru kanker serviks di indonesia akan meningkat sebesar $74 \%$, sementara secara keseluruhan prevalensinya akan meningkat sebesar 49\%. WHO (world health organization) merekomendasikan semua wanita yang telah menikah atau telah berhubungan seksual untuk menjalani pemeriksaan pap smear minimal setahun sekali. Pap smear adalah suatu metode dimana dilakukan pengambilan sel dari mulut rahim kemudian di periksa di bawah mikroskop. Pada pemeriksaan biasanya dapat di tentukan apakah sel yang ada di mulut rahim masih normal, berubah menuju kanker atau telah berubah menjadi sel kanker (Kumalasari \& Andhyantoro, 2012).

Oleh karena itu penulis tertarik untuk mereview artikel tentang hubungan pengetahuan wanita usia subur (WUS) tentang pap smear dengan keikutsertaan melakukan pemeriksaan pap smear.

\section{Metode Penelitian}

Studi literature review adalah cara yang dipakai untuk megumpulkan data atau sumber yang berhubungan pada sebuah topik tertentu 
yang bisa didapat dari berbagai sumber seperti jurnal, buku, internet, dan pustaka lain. Desain penelitian ini adalah literature review dengan metode literatur review sederhana.

\section{Hasil dan Pembahasan}

\section{Pengetahuan Wus}

Penulis menelaah dua puluh hasil penelitian tentang pengetahuan, didapatkan hasil bahwa tiga hasil penelitian menunjukan bahwa pengerathuan responden kurang dan dua peneitian menunjukan pengetahuan responden baik.

Penelitian yang dilakukan oleh (Annisa, 2016) Menunjukkan distribusi frekuensi berdasarkan pengetahuan. Pengetahuan responden terbanyak adalah pengetahuan baik sebanyak 33 orang dengan persentase $25.0 \%$.

Penelitian yang dilakukan oleh erma retnaningtyas menunjukan bahwa hampir setengah dari PUS di desa joho kecamatan wates kabupaten kediri memiliki pengetahuan kurang yaitu sebanyak $42,9 \%$ (27 responden) dari total responden sebanyak 63 responden, dikarenakan hampir sebagian responden tidak mengetahui tentang pentingnya melakukan pemeriksaan pap smear untuk mendeteksi kanker servik (Retnaningtyas, 2018).

Penelitian yang dilakukan oleh (Heryani, 2018) menunjukan bahwa pengetahuan responden tentang pap smear terbanyak pada pengetahuan kurang sebanyak 29 orang $(43,9 \%)$.

Penelitian yang dilakukan oleh kiky kusuma ningrum rekuensi tertinggi adalah responden yang mempunyai pengetahuan baik adalah 13 responden $(43,33 \%)$ dan frekuensi terendah adalah responden yang mempunyai pengetahuan kurang 6 responden $(20 \%)$.
Penelitian yang dilakukan oleh (Rosdiana, 2019) menunjukan bahwa pengetahuan yang baik berjumlah 41 responden $(48,2 \%)$ lebih sedikit dari pengetahuan yang kurang berjumlah 44 responden $(51,8 \%)$.

Seseorang akan melakukan tindakan berdasarkan pengetahuan yang dimilikinya serta akan mengaplikasikannya, semakin baik pengetahuan seseorang tentang kanke rserviks maka orang tersebut akan melakukan tindakan pemeriksaan pap smear dan sebaliknya jika pengetahuan seseorang kurang tentang kanker serviks maka orang tersebut tidak akan melakukan pemeriksaan pap smear setiap tahunnya. Peneliti menelaah bahwa pengetahuan baik responden dikarenakan faktor pendidikan responden dalam penelitian yang menunjukan pengetahuan baik mayoritasnya adalah berpendidikan tinggi. Seseorang yang berpendidikan lebih tinggi akan mempunyai pengetahuan yang lebih luas dibandingkan seseorang yang tingkat pendidikannya lebih rendah. Tingkat pendidikan merupakan salah satu faktor yang mempengaruhi pengetahuan seseorang. Selain itu, peneliti berpendapat bahwa informasi yang didapat oleg responden juga mempengaruhi pengetahuan responden. Sebagaimaa yang di katakan oleh (Notoatmodjo, 2012) Semakin banyak informasi yang didapat maka semakin bertambah pula pengetahuannya. Seorang wanita usia subur yang tidak pernah mendapat informasi atau pengetahuan tentang kanker serviks tentu beda dengan wanita usia subur yang sudah mengerti, pengetahuannya akan lebih banyak dan lebih memahami tentang apa itu kanker. Pernah atau belumnya mendapatkan informasi merupakan faktor yang mempengaruhi pengetahuan wanita usia subur tentang kanker serviks. informasi 
tersebut bisa diperoleh dari sumbersumber seperti orang tua, teman/saudara, tenaga kesehatan, maupun media massa.

\section{Pemeriksaan Pap Smear}

Penulis menelaah dua puluh hasil penelitian tentang pemeriksaan pap smear, didapatkan hasil bahwa tiga hasil penelitian menunjukan bahwa responden tidak pernah atau tidak ada minat untuk melakukan pap smear dan dua peneitian menunjukan responden berminat dalam keikutsertaan melakukan pap smear.

Penelitian yang dilakukan oleh (Annisa, 2016) Menunjukkan bahwa Pemeriksaan pap smear responden terbanyak adalah responden yang melakukan tindakan pemeriksaan pap smear yaitu sebanyak 27 orang dengan persentase $61.4 \%$

Penelitian yang dilakukan oleh erma retnaningtyas menunjukan bahwa responden yang belum pernah melakukan pemeriksaan pap smear sebanyak 45 orang dan yang belum pernah sebanyak 18 orang.

Penelitian yang dilakukan oleh (Heryani, 2018) menunjukan bahwa bahwa responden yang tidak melakukan pemeriksaan pap smear sebanyak 53 orang dan yang tidak melakukan pemeriksaan pap smear sebanyak 13 orang

Penelitian yang dilakukan oleh Kiky Kusuma Ningrum didapatkan hasil bahwa bahwa frekuensi tertinggi adalah responden yang mempunyai minat tinggi yaitu 26 responden $(86,67 \%)$ dan yang mempunyai frekuensi terendah adalah responden yang mempunyai minat sedang yaitu 4 responden (13,33\%).

Penelitian yang dilakukan oleh (Rosdiana, 2019) menunjukan bahwa didapatkan hasil dari 85 responden, memilih metode Pap Smear berjumlah 15 responden $(17,6 \%)$ lebih sedikit dari yang tidak memilih metode Pap Smear berjumlah 70 responden $(82,4 \%)$.

Penulis menelaah hasil penelitian menunjukan bahwa responden yang tidak pernah atau tidak ada minat untuk melakukan pap smear disebabkan karena lebih banyak responden berpengetahuan kurang tentang pap smear pada penelitian tersebut yang kemungkinan penyebabnya adalah kurangnya informasi dan tingkat pendidikan yang rendah.

Alasan kenapa wanita mau melakukan pap smear dikarenakan adanya pengetahuan wanita tentang bahaya kanker, pap smear dilakukan bertujuan untuk mengetahui ada atau tidaknya proses infeksi, kelainan pra kanker dan kanker di vagina dan serviks (Lestadi, 2017). Hasil pemeriksaan pap smear dapat menunjukkan adanya penyakit lain dalam vagina dan serviks, diantaranya yaitu infeksi Human papillomavirus yang memiliki hubungan yang kuat dengan kejadian kanker serviks. Dengan diketahuinya penyakit atau keabnormalan pada vagina atau serviks dari hasil pemeriksaan pap smear, maka dapat dilakukan pengobatan yang seksama sehingga akibat lebih lanjut menjadi kanker serviks dapat dihindari. Hal ini dapat dilhat dari jurnal yang ditelaah yang menunjukan bahwa responden yang tidak pernah atau tidak ada minat untuk melakukan pap smear disebabkan karena lebih banyak responden berpengetahuan kurang tentang pap smear pada penelitian tersebut yang kemungkinan penyebabnya adalah kurangnya informasi dan tingkat pendidikan yang rendah, begitupun sebaliknya, responden yang pernah atau ada minat untuk melakukan pap smear disebabkan karena lebih banyak responden berpengetahuan baik. 


\section{Pokok Bahasan Hubungan}

\section{Pengetahuan Dengan Pemeriksaan Pap Smear}

Penulis menelaah dua puluh hasil penelitian tentang hubungan pengetahuan wanita usia subur (WUS) tentang pap smear dengan keikutsertaan melakukan pemeriksaan pap smear, didapatkan hasil bahwa lima penelitian dari artikel yang penulis telaah menunjukan ada hubungan antara pengetahuan wanita usia subur (WUS) tentang pap smear dengan keikutsertaan melakukan pemeriksaan pap smear.

Penelitian yang dilakukan oleh (Annisa, 2016) Menunjukkan bahwa terdapat hubungan secara signifikan antara pengetahuan wanita usia subur tentang kanker serviks dengan tindakan pemeriksaan pap smear dengan hasil uji fisher exact test diperoleh $\mathrm{p}$ value 0,000 . Responden yang berpengetahuan baik sebanyak 33 responden, 78,8\% diantaranya melakukan pemeriksaan pap smear sedangkan sisanya $21,2 \%$ tidak melakukan pemeriksaan pap smear. Responden yang berpengetahuan buruk sebanyak 11 responden, hanya 1 responden yang melakukan pemeriksaan pap smear, hal ini menunjukkan terdapat keterkaitan baik dan buruknya pengetahuan terhadap tindakan pemeriksaan pap smear.

Penelitian yang dilakukan oleh Erma Retnaningtyas menunjukan bahwa Dari hasil uji statistik spearman rank dengan nilai $\mathrm{a}=0,05$ didapatkan nilai $\mathrm{p}=0,000<$ 0,05 sehingga dapat disimpulkan bahwa $\mathrm{H} 0$ ditolak dan $\mathrm{H} 1$ diterima yang artinya ada hubungan pengetahuan tentang pemeriksaan pap smear pada PUS di desa joho kecamatan wates kabupaten kediri.

Penelitian yang dilakukan oleh (Heryani, 2018) menunjukan bahwa Hasil penelitian dengan uji statistic chi square menunjukan bahwa terdapat hubungan yang bermakna antara pengetahuan ibu tentang pap smear dengan pelaksanaan pemeriksaan pap smear, dimana $\mathrm{p}<0,05$ $(\mathrm{p}=0,000)$.

Penelitian yang dilakukan oleh (Ningrum, 2017) didapatkan hasil bahwa dari perhitungan uji spearmank rank menunjukkan hasil koefisien sebesar 0,668 dengan taraf signifikansi sebesar 0,000 maka H1 diterima. Berdasarkan hasil penelitian dapat disimpulkan bahwa ada hubungan pengetahuan wanita usia subur tentang kanker serviks dengan minat melakukan pap smear.

Penelitian yang dilakukan oleh (Rosdiana, 2019) menunjukan bahwa didapatkan hasil analisis bivariat menunjukkan pada kelompok responden berpengetahuan baik yang memilih metode pap smear berjumlah 11 responden (26,8\%) sedangkan pada responden dengan pengetahuan kurang yang memilih metode pap smear sebanyak 4 responden $(9,1 \%)$. Hasil uji chi-square menunjukkan $p$ value $=0,063$ lebih kecil daripada nilai $\mathrm{a}=0,05$ yang berarti ada hubungan yang bermakna antara pengetahuan dengan pemilihan metode pap smear di rumah sakit islam Siti Khadijah palembang tahun 2019.

Penelitian yang dilakukan oleh (Annisa, 2016) Menunjukkan bahwa terdapat hubungan secara signifikan antara pengetahuan wanita usia subur tentang kanker serviks dengan tindakan pemeriksaan pap smear. Hasil penelitian menunjukan dari 33 responden berpengetahuan baik, $78,8 \%$ memilih tindakan pemeriksaan pap smear sedangkan sisanya $21,2 \%$ tidak memilih tindakan pemeriksaan pap smear. Sebaliknya, terdapat kecenderungan responden yang berpengetahuan buruk memilih tidak melakukan pap smear. 
Penulis berpendapat bahwa pengetahuan merupakan awal dari perubahan perilaku. Artinya jika ingin mengubah perilaku dari yang tidak melakukan pemeriksaan pap smear menjadi mau melakukan pemeriksaan pap smear, maka mulailah dari meningkatkan pengetahuan terlebih dahulu. Peningkatan pengetahuan ini dapat dilakukan dengan memberikan informasi seluas-luasnya kepada ibu akan pentingnya pemeriksaan pap smear. Sesuai dengan teori yang dikemukakan (Aziz,2017) pengetahuan ibu tentang kanker servik akan membentuk sikap positif terhadap deteksi dini kanker servik. Hal ini juga merupakan faktor kedua dominan dalam pemeriksaan deteksi dini kanker serviks. Pengetahuan yang dimiliki WUS tersebut akan menimbulkan kepercayaan ibu tentang deteksi dini kanker serviks.

Pengetahuan atau kognitif merupakan domain yang sangat penting dalam membentuk tindakan seseorang, proses adopsi perilaku yang didasari oleh pengetahuan akan lebih baik dari pada perilaku yang tidak didasari oleh pengetahun. Pengetahuan diperlukan sebagai dorongan fisik dalam menumbuhkan rasa percaya diri sehingga dikatakan bahwa pengetahuan merupakan stimulus terhadap tindakan seseorang (Notoatmodjo, 2011).

Pengetahuan tidak hanya diperoleh dari pendidikan formal, tetapi juga bisa diperoleh dari pelatihan, penyuluhan, teman, brosus. Dari informasi tersebut maka pengetahuan yang dimiliki semakin meningkat sehingga kemungkinan untuk melakukan pemeriksaan pap smear semakin besar.

Menurut asumsi penulis, dari lima artikel yang ditelaah menunjukan bahwa pengetahuan ibu mengenai faktor yang membuat ibu melakukan pap smear mayoritas berpengetahuan tinggi karena tingkat pengetahuan ibu tentang pap smear sangat bagus dan sebaliknnya bahwa pengetahuan ibu mengenai faktor yang membuat ibu tidak melakukan pap smear mayoritas berpengetahuan kurang. Hal ini disebabkan karena faktor informasi yang didapatkan ibu tentang pap smear sehingga, jika mereka berusaha untuk mencari informasi yang lebih mendalam tentang pemeriksaan pap smear maka akan semakin bertambah pengetahuan ibu dan minat untuk melakukan pemeriksaan pap smear akan semakin tinggi dan sebaliknya ,jika mereka tidak berusaha untuk mencari informasi yang lebih mendalam tentang pemeriksaan pap smear maka pengetahuan ibu akan terbatas dan minat untuk melakukan pemeriksaan pap smear akan semakin rendah.

\section{Kesimpulan}

Kesimpulan dari literature review ini adalah penelitian yang dilakukan oleh (Annisa, 2016) Menunjukkan distribusi frekuensi berdasarkan pengetahuan. Pengetahuan responden terbanyak adalah pengetahuan baik sebanyak 33 orang dengan persentase $25.0 \%$. Penelitian yang dilakukan oleh erma retnaningtyas menunjukan bahwa hampir setengah dari PUS di desa joho kecamatan wates kabupaten kediri memiliki pengetahuan kurang yaitu sebanyak 42,9\% (27 responden) dari total responden sebanyak 63 responden, dikarenakan hampir sebagian responden tidak mengetahui tentang pentingnya melakukan pemeriksaan pap smear untuk mendeteksi kanker servik. Penelitian yang dilakukan oleh (Heryani, 2018) menunjukan bahwa pengetahuan responden tentang pap smear terbanyak pada pengetahuan kurang sebanyak 29 orang $(43,9$ $\%)$. 


\section{BIBLIOGRAFI}

Annisa, W. N. (2016). Hubungan Antara Pengetahuan Wanita Usia Subur Tentang Kanker Serviks Dan Tindakan Pemeriksaan Pap Smear Di Kelurahan Sidanegara Kabupaten Cilacap. Universitas Muhammadiyah Surakarta.

Aziz. (2017). Menaklukkan Kanker Serviks Dan Kanker Payudara Dengan 3 Terapi Alami. Agromedia.

Heryani, R. (2018). Hubungan Pengetahuan Wanita Terhadap Pemeriksaan Papsmear Di Wilayah Puskesmas Garuda Kota Pekanbaru. Jurnal Endurance: Kajian Ilmiah Problema Kesehatan, 3(3), 596-602.

Kemenkes. (2017). Informasi Kementrian Kesehatan Ri. 2014. Situasi Dan Analisis Lanjut Usia.

Kumalasari, I., \& Andhyantoro, I. (2012). Kesehatan Reproduksi Untuk Mahasiswa Kebidanan Dan Keperawatan. Jakarta: Salemba Medika, 14, 22.

Ningrum, K. K. (2017). Hubungan Pengetahuan Wanita Usia Subur Tentang Kanker Serviks Dengan Minat Melakukan Pap Smear Di Rt 16 Kelurahan Blabak Kecamatan Pesantren Kota Kediri. Jurnal Kebidanan, 6(2), 122-130.

Notoatmodjo, S. (2011). Kesehatan Masyarakat Ilmu Dan Seni.

Notoatmodjo, S. (2012). Metodologi Penelitian Kesehatan.

Ocviyanti, D., Rosana, Y., \& Wibowo, N. (2009). Profil Flora Vagina Dan Tingkat Keasaman Vagina Perempuan Indonesia. Majalah Obstet Ginekol Indonesia, 33, 124-131.
Retnaningtyas, E. (2018). Hubungan Pengetahuan Dan Sikap Dengan Pemeriksaan Pap Smear Pada Pasangan Usia Subur (Pus) Di Desa Joho Kecamatan Wates Kabupaten Kediri. Journal For Quality In Women's Health, 1(1), 13-19.

Rosdiana, M. (2019). Hubungan Antara Paritas Dan Pengetahuan Wanita Usia Subur Terhadap Pemilihan Metode Pap Smear Di Rumah Sakit Islam Siti Khadijah Palembang Tahun 2019. Prosiding Seminar Nasional, 106-113.

Saifuddin, A. (2016). Sikap Manusia Teori Dan Pengukurannya. Yogyakarta: Pustaka Pelajar Offset.

Tilong, A. D. (2012). Bebas Dari Ancaman Kanker Serviks. Yogyakarta: Flashbooks.

Yki. (2014). Tentang Yki. Tersedia Dalam Www. Yayasankankerindonesi A. Org. 